\title{
An investigation on the forms of information sources and services utilised among rural dwellers from public libraries in the North-West zone of Nigeria
}

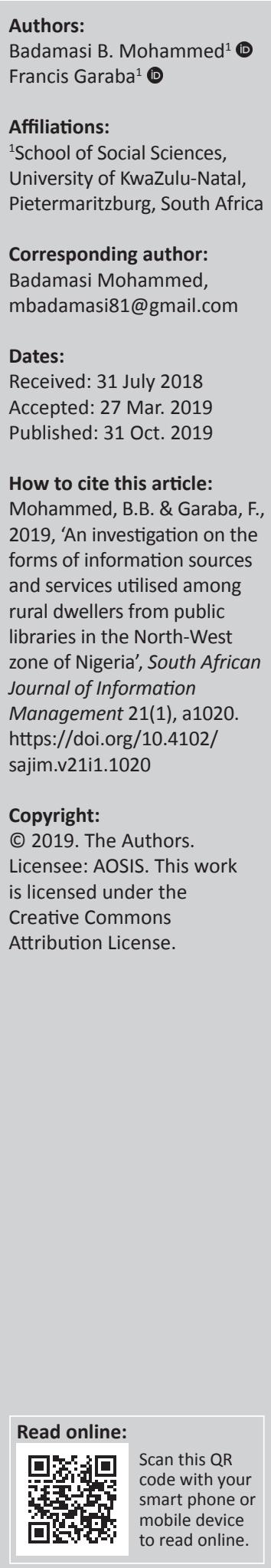

Background: Rural dwellers need timely, accurate, pertinent and reliable information for sustainable rural development. However, in Nigeria it is estimated that over $70 \%$ of people are living in rural areas who are mainly non-literate people who cannot read and write in any language. It is against this background that this article sought to investigate the forms of information sources and services utilised among rural dwellers from public libraries in the North-West zone of Nigeria to find out whether they are relevant and appropriate to the nature of this group of people.

Objectives: The study aimed at investigating the forms of information sources and services utilised among rural dwellers from public libraries in the North-West zone of Nigeria for sustainable rural development.

Method: Wilson's 1981 model suggests that information-seeking behaviour arises as a result of a need perceived by an information user, who, in order to satisfy that need, makes demands upon formal or informal information sources and services. Hence, the model was adopted to underpin the current study. A structured questionnaire was designed and personally administered to the study participants. The quantitative data were analysed using the SPSS software and descriptive statistics.

Results: Despite the fact that most of the rural dwellers in the North-West zone of Nigeria are non-literate people, it is evident from the results that there is utilisation of various forms of information sources and services from public libraries. The predominant forms of information sources utilised among rural dwellers from the libraries were printed materials, posters, flyers and audiovisuals. However, the forms of information services provided to rural dwellers by the libraries were traditional library services and awareness campaigns about government policies.

Conclusion: The study revealed that utilisation of public libraries' information sources and services among rural dwellers in the area under study revolved around printed materials and traditional library services. It is evident that most of the library users among rural dwellers were those who were literate, as the non-literate people who were the majority did not patronise the libraries. Thus, this study will assist authorities of the public libraries in the area under study to provide relevant and effective information sources and services to rural dwellers for sustainable rural development.

Keywords: Utilisation; information sources; information services; public libraries; rural dwellers.

\section{Introduction}

Information is a vital tool for addressing societal challenges for sustainable development. Rural people need information for the development of their communities in various spheres of life (Momodu 2012:91). Information comes in various formats and languages, targeted at various categories of users. Tabor (2009:2) noted that people in rural areas are more accustomed to oral tradition and can better relate to information exchanged in that way. Public libraries have an important role in the provision of relevant and effective information sources and services in formats and languages best understood by rural dwellers for sustainable development. Thus, the development of any rural community is a positive indicator of the development of a nation, and information dissemination through public libraries is an essential ingredient in the development of rural communities (Sultana 2014:27). Ejedafiru (2015:48) argues that rural 
populace cannot become knowledgeable and powerful if they do not have relevant information to empower their thinking and enhance their understanding.

Information sources serve as a means of disseminating or communicating information to rural dwellers. Thus, information sources or channels are considered the most important aspect of an information system in a society (Williamson 1998). Anyanwu (2008) is of the opinion that no matter how relevant information might be, if it is wrongly packaged or transferred, it will never reach the target audience successfully. Wilson's 1981 model suggests that information-seeking behaviour arises from the recognition of a need perceived by an information user, who, in order to satisfy that need, seeks information from formal or informal sources that may result in success or failure. Therefore, it is universally accepted that the improvement in the living conditions of a population largely depends on the appropriate channel used in disseminating information to that population (Momodu 2012:91).

Therefore, the provision of effective information services is the main aim of public libraries in order to satisfy the information needs of their users. Provision of public library and information services entails acquiring, organising and making relevant information resources accessible through appropriate facilities and means best known to the users (Iwhiwhu \& Okorodudu 2012). Thus, the provision of public library services is a way of improving the levels of literacy and education of users, and enhancing their capability to effectively use information relevant to their daily lives (Oni, Nomuje \& Oshiotse 2014).

\section{Review of related literature}

Effective dissemination of information to rural dwellers requires the choice of appropriate information sources or channels. Chinwe, Ogbonna and Osuchukwu (2014) carried out research with a focus on information needs of rural dwellers in Nigeria and found that the information sources available in local information centres included textbooks, newspapers or magazines, picture books, audiovisuals, television and radio, among others. According to the Food and Agriculture Organization (FAO) of the United Nations (2006:3), in rural areas information, knowledge and skills meant for development are exchanged between farmers, extension or advisory officers, information providers and researchers through personal contact or through media such as radio, print and, more recently, the new information and communication technologies (ICTs). As such, information dissemination to rural communities requires appropriate channels of communication (Daudu \& Mohammed 2013:235).

Furthermore, information sources facilitate the informationseeking activities of library users in seeking and satisfying their information needs from public libraries. Aina's 2006 library-extension service linkage model suggests that information materials, such as audio- and videocassettes, audio- and videorecording players, films, projectors, posters and leaflets on agriculture are expected to be collected by the library and serve as channels for information transfer to rural dwellers.

The issues surrounding the utilisation of public libraries' information sources and services among rural dwellers have attracted the attention of many scholars and writers around the world. For example, in the USA, Hildreth (2007:7) clearly pointed out that there was serious concern about the future of rural libraries and indicated that the rural libraries are at a turning point. A study by Sultana (2014:27) found that little attention had been given to the role of rural public libraries in the overall development in India. Sultana observed that rural libraries have not been developed, and that the principal victims have been the rural communities, who, because of information poverty, lack the individual means of becoming literate, and because of their level of illiteracy, poverty or poor health. Nyana (2009:9) observed that the major hindrances to effective provision of information and services in Africa were inappropriate collections, high levels of illiteracy and lack of incorporating oral tradition into the provision of information services, among others. Salman, Mostert and Mugwisi (2014:38) opine that in Africa, public libraries should be charged with the responsibility of providing information services to support local businesses and economic and workforce development, among others.

Information is needed by all and sundry in order to know what is going on in the society, to acquire basic needs of life, as well as to cope with every given situation (Nwalo \& Madukoma 2012:61). In the USA, for example, Vavrek (1995:36) reported that the information needs of rural Americans were centred on social activities such as hobbies and/or crafts, local business or investment, action of government officials, how to reference, legal matters, local history and genealogy, local news, national news and health or medical services, among others. In China, Zou and Zou (2014:114) reported that the information needs of elderly people in rural communities revolved around physiological needs, such as food, clothing, shelter, action, healthcare and pension policy information.

In Asia, research from Malaysia (Yusop et al. 2013), Bangladesh (Islam 2006) and India (Bachhav 2012; Omar et al. 2012; Thanuskodi \& Pandiselvi 2014) showed that the information needs of rural dwellers in these countries are largely concerned with agriculture in general, medical and health matters, education development, religion, culture and business, among others. In Africa, research from South Africa (Jiyane 2002:16; Maepa 2000), Botswana (Mutshewa et al. 2010:4) and Tanzania (Mtega \& Ronald 2013:69) has shown that the information needs of rural dwellers revolved around various areas, such as pension, business, crime, agriculture, transport, proper housing, transport and communication systems and basic healthcare. 
In the Nigerian context, research carried out by Ape (2012), Emmanuel (2012), Momodu (2012), Udofia (2012), Daudu and Mohammed (2013), Idiegbeyan-Ose et al. (2015), Patience (2015) and Ezema (2016) showed that the information needs of rural communities can generally be categorised into health, agriculture, education, housing, employment and transportation, among others.

In Nigeria, research by Emmanuel (2012), Daudu and Mohammed (2013), Ifukor (2013), Anie (2014), Annune, Ezeani and Okafor (2014), Idiegbeyan-Ose et al. (2015) and Odefadehan, Akinola and Odefadehan (2016) showed that the information sources or channels used in disseminating information to rural dwellers include town criers, oral information from neighbours, friends, age groups, elders, farmers groups, village leaders, agricultural extension officers, family and/or parents, radio, TV, Internet, books, brochures, films, leaflets, newspapers and magazines, colleagues, marketplaces, mobile phones, sociopolitical meetings, traditional festival, songs and dance, and many more. Research conducted by Uzuegbu (2016) concurred that mass media, and other sources or channels such as information systems, education and training, agents, personal contacts and miscellaneous channels, were the right channels of disseminating information in the rural areas.

As regards the information services, studies from Nigeria by Omopupa (2006), Ebiwolate (2010), Saleh and Lasisi (2011), Enemute and Okorodudu (2012), Oyeronke (2012), Akinola et al. (2013), Chinwe et al. (2014), Joy and Idowu (2014) and Obasi (2015) revealed that public library and information services generally revolve around reference services, storytelling services, film show services, career information services, online Internet services, lending services and photocopying services. Others include telephone, recreational and advisory services, current awareness, selective dissemination of information, bookmobiles, referral services, translation services, outreach and extension services, adult literacy programmes, audiovisual services, packaging and repackaging of information services and many more.

The above discussion, indicates that there is an existing knowledge gap in the literature, as it is silent on the situation on utilisation of public libraries' information sources and services among rural dwellers in the North-West zone of Nigeria. This is what this study seeks to address through empirical investigation.

\section{Theoretical framework}

Wilson's 1981 model of information behaviour was adopted to explain the forms of information sources and services utilised among rural dwellers from public libraries in the area under study.

Figure 1 suggests that Wilson's 1981 model of information behaviour was adequate in addressing all the research questions in this study. The basic and relevant construct in

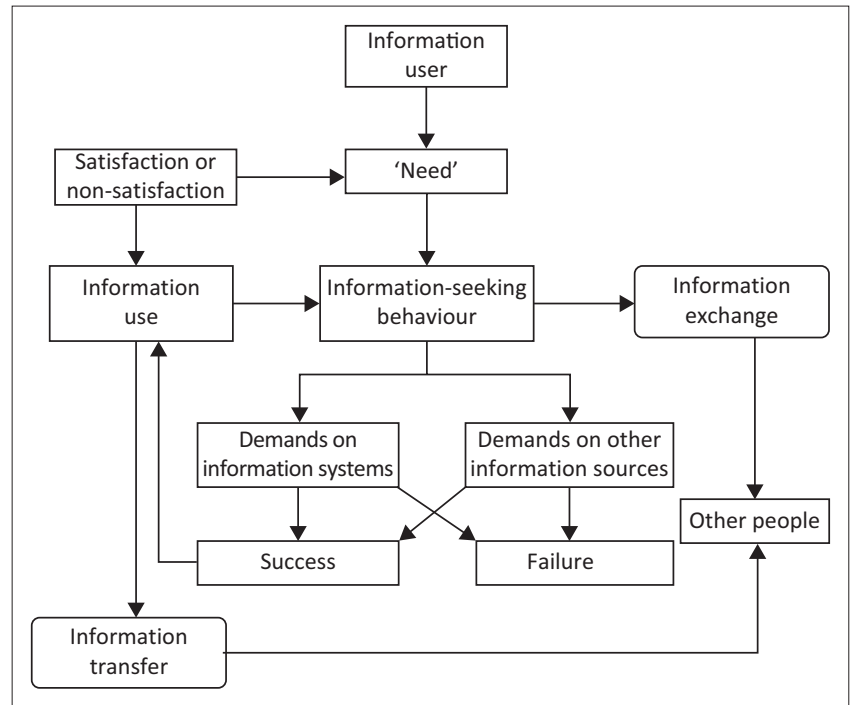

Source: Wilson, T.D., 1981, 'On user studies and information needs', Journal of Documentation 37(1), 3-15.https://doi.org/10.1108/eb026702

FIGURE 1: Wilson's (1981) information behaviour model.

the model that guided the current study in addressing the research questions were information needs, sources, services and use. Wilson's 1981 model of information behaviour suggests that information-seeking behaviour arises as a result of a need perceived by an information user, who, in order to satisfy that need, makes demands upon formal or informal information sources or services, which result in success or failure (Wilson 1999:251). Thus, the basis of this study was on these constructs of the model.

Accordingly, the following research questions were addressed:

- What are the information needs of rural dwellers in the North-West zone of Nigeria?

- To what extent are information sources and services utilised among rural dwellers from public libraries in the North-West zone of Nigeria?

- What forms of information sources and services are utilised among rural dwellers from public libraries in the North-West zone of Nigeria?

\section{Methodology}

The study was carried out in 52 functional branch or public libraries in local government areas in the zone under study. These libraries were established to cater for the information needs of rural communities. Thus, they are controlled by the public library boards of Kaduna, Katsina, Jigawa, Kebbi and Zamfara states. A survey research method was used to carry out this study. The study population comprised two groups of participants. The first group of participants involved 10574 registered library users (aged 18 years and above), which included both literate and illiterate people. The second group comprised 52 heads of the branch libraries. The total population for each of the two groups in each of the five states is presented in Table 1. 
For the sample size, all the 52 heads of functional branch or public libraries in the local government across the study area were recruited automatically (because their population was small). A sample of 370 participants were also recruited from the 10574 registered library users, using Krejcie and Morgan's (1970) theory of determining the sample size. Because the population of the library users is very large, sampling is necessary. According to Krejcie and Morgan's (1970) theory of determining the sample size, if the total population of a study falls between 10000 and 14 999, then the sample should be 370 participants.

To ensure proportional representativeness in the sample size, a proportionate random sampling technique (criteria) was used to recruit the 370 participants. This technique was chosen in order to ensure that the researcher does not leave the representativeness of the sample entirely to chance as suggested by Abbas (2009). It also ensures that the sample is similar to the population of the study in certain respects based on the total population from each state. Thus, in recruiting the 370 participants, the researcher used a formula recommended by Krejcie and Morgan's (1970) theory of determining the sample size, as presented below:

$$
\frac{\mathrm{N} \times \mathrm{S}}{\mathrm{TP}}
$$

Where:

- $\mathrm{N}=$ Number (population from each state)

- $\mathrm{S}=$ Sample (total sample size)

- $\mathrm{TP}=$ Total population

Thus, the sample size for the library users in each of the five states under study is proportionately calculated as follows (see Equation 2 and Table 2):

\begin{tabular}{llll}
\hline TABLE 1: Population of the study. & \\
\hline $\mathbf{S} / \mathbf{N}$ & $\begin{array}{l}\text { Total number of } \\
\text { states in the North- } \\
\text { West zone of Nigeria }\end{array}$ & $\begin{array}{l}\text { Total number of heads } \\
\text { of functional branch } \\
\text { public libraries }\end{array}$ & $\begin{array}{l}\text { Total number of } \\
\text { registered library users }\end{array}$ \\
\hline 2 & Kaduna State & 9 & 950 \\
\hline & Kano State & $\begin{array}{l}\text { The branch public } \\
\text { libraries in this state } \\
\text { were shut down for } \\
\text { renovation and general } \\
\text { reorganisation. }\end{array}$ & $\begin{array}{l}\text { The branch public } \\
\text { libraries in this state } \\
\text { were shut down for } \\
\text { renovation and general } \\
\text { reorganisation. }\end{array}$ \\
\hline 3 & Sokoto State & $\begin{array}{l}\text { The branch public } \\
\text { libraries in this state } \\
\text { were yet to be } \\
\text { operational. }\end{array}$ & $\begin{array}{l}\text { The branch public } \\
\text { libraries in this state } \\
\text { were yet to be } \\
\text { operational. }\end{array}$ \\
\hline 4 & Katsina State & 22 & 1113 \\
\hline 5 & Jigawa State & 14 & 3037 \\
\hline 6 & Kebbi State & 5 & 2456 \\
7 & Zamfara State & 2 & 3018 \\
\hline & Total & $\mathbf{5 2}$ & $\mathbf{1 0 5 7 4}$ \\
\hline $5 / N$, & &
\end{tabular}

$\mathrm{S} / \mathrm{N}$, serial number.

TABLE 2: Sample size of the study: Proportionate sample from each state unde study.

\begin{tabular}{llcccccc}
\hline S/N & Participants & Kaduna & Katsina & Jigawa & Kebbi & Zamfara & Total \\
\hline 1 & $\begin{array}{l}\text { Heads of public libraries in } \\
\text { the local government areas }\end{array}$ & 9 & 22 & 14 & 5 & 2 & 52 \\
2 & Library users & 33 & 39 & 106 & 85 & 107 & $\mathbf{3 7 0}$ \\
- & Total & 42 & 61 & 120 & $\mathbf{9 0}$ & $\mathbf{1 0 9}$ & $\mathbf{4 2 2}$ \\
\hline
\end{tabular}

$\mathrm{S} / \mathrm{N}$, serial number.
Kaduna State $950 \times 370=32.69(33)$

10574

Katsina State $1113 \times 370=38.95(39)$

10574

Jigawa State $3037 \times 370=106.27(\mathbf{1 0 6})$

10574

Kebbi State $2456 \times 370=85.94(85)$

10574

Zamfara State $3081 \times 370=107.81(\mathbf{1 0 7})$

10574

Total $=370$

[Eqn 2]

Table 2 indicates that the total sample size for this study comprised 52 heads of functional branch or public libraries in the local government areas and 370 library users. In total, the sample size for the study is 422 participants.

Two sets of questionnaires were designed to collect data from both groups of participants and a Likert scale technique was used. The participants were presented with a range of answer options to indicate whether they strongly agreed, agreed, disagreed, strongly disagreed or were not sure about each item question. The questionnaire for the library users was also translated into Hausa for non-literate library users. Hausa is the common language spoken across the zone under study. The questionnaires were administered personally by the researcher with the help of research assistants. The English version questionnaire was self-completed, while the translated questionnaire was interviewer-completed. In essence, it was read out to the non-literate participants at the site of data collection for their effective responses. The research assistants were trained on how to administer both the English version and Hausa-translated questionnaires. Thus, the questionnaires were designed to collect data on information needs of rural dwellers, information sources and services utilised among the library users as rural dwellers. The responses to each of the items on the questionnaires are presented and analysed in tables of frequencies and percentages using SPSS software and descriptive statistics.

As regards the ethical considerations, the ethical requirements of the Humanities and Social Sciences Research Ethics Committee of the University of KwaZulu-Natal were strictly adhered to. During the data collection process the researcher, who is versed in Hausa language explained the main purpose of the study to the participants for clarification. This was done to reassure them of total confidentiality and develop trust. They were assured that the information elicited from them would be used strictly for academic purposes. Informed consent forms were introduced to the participants in order to obtain their consent for participation in the study. This was also done to assure them of their anonymity and their rights to withdraw from the research at any time without any consequences.

\section{Presentation and analysis of results}

A total of 332 and 51 questionnaires were duly completed and retrieved from the library users and heads of branch libraries, respectively, with a response rate of $89.7 \%$ 
and $98.1 \%$. This was achieved as a result of the strong followups as well as the employment of research assistants in the administration and retrieval of the research instruments.

\section{Demographic variables of the participants}

The findings of this study reveal that men dominated the study population more than women. This indicates that there were more men involved in the utilisation of public library services in the area under study. Only three (5.9\%) of the heads of branch libraries were women, while 48 (94.1\%) heads were men. As regards the users, $238(71.7 \%)$ were men and 94 (28.3\%) were women. This development can basically be attributed to the religious and cultural restrictions on women in this geo-political zone. The study also found that the common age among the heads of the branch libraries was generally 45 years and above, with a few below 45 years. Thus, the majority of the heads of branch libraries were mature, middle-aged people. The most common age group of the library users ranged from 18 to 27 years and from 28 to 37 years. Most of the library users were younger people, meaning that young people have the ability to access and utilise information sources and services from public libraries. Another factor is that this is the stage where young people strive to self-actualise themselves for sustainable rural development.

From Table 3, in terms of educational qualification, over half $(64.7 \%)$ of heads of the branch libraries were

TABLE 3: Distribution of the participants by their highest educational qualifications.

\begin{tabular}{lcccccc}
\hline Educational qualification & \multicolumn{2}{c}{ Heads of branch libraries } & & \multicolumn{2}{c}{ Library users } \\
\cline { 2 - 3 } \cline { 6 - 7 } & Frequency & $\mathbf{\%}$ & & Frequency & $\%$ \\
\hline No formal schooling & - & - & & 7 & 2.1 \\
Non-formal Islamic education & - & - & & 22 & 6.6 \\
Elementary & - & - & & 6 & 1.8 \\
O level & - & - & & 59 & 17.8 \\
Certificate & 13 & 25.5 & & 31 & 9.3 \\
Diploma/NCE & 33 & 64.7 & & 93 & 28.0 \\
Degree/HND & 5 & 9.8 & & 108 & 32.5 \\
Master's degree & - & - & & 6 & 1.8 \\
\hline Total & $\mathbf{5 1}$ & $\mathbf{1 0 0}$ & & $\mathbf{3 3 2}$ & $\mathbf{1 0 0}$ \\
\hline
\end{tabular}

NCE, Nigerian Certificate in Education; HND, Higher National Diploma.
Diploma/Nigerian Certificate in Education (NCE) holders. The findings thus indicate that only a few $(5 ; 9.6 \%)$ heads of the branch libraries had a Bachelor's degree in librarianship. This lack of a degree among heads of branch libraries is a cause of concern, as these figures showed the poor qualification attainment by this group of participants. According to Nwokocha (1998:101), the public library like any other organisation needs adequate, well-trained, dedicated and experienced personnel to carry out the library services effectively and efficiently. This finding indicates that there was a lack of training and retraining of library staff, which could be attributed to poor funding of the libraries. Opara (2008:352) noted that public libraries are not adequately funded in Nigeria; in fact, all other problems of the libraries have emanated from the poor funding. Opara (2008:356) further observed that the libraries ought to be headed by professionals but were instead headed by para-professionals or even non-professionals, including branch libraries in some local government areas.

Table 3 further shows that most of the library users possessed a Diploma or NCE degree as well as a degree/Higher National Diploma (HND). The findings reveal that 93 (28.0\%) and 108 (32.5\%) library users, respectively, possessed these qualifications. This distribution implies that most of the rural dwellers that patronised public library services in the area under study were considered relatively educated. The reasons for non-use of the libraries by the majority of non-literate people could be attributed to the forms of information resources and services offered by the libraries, as highlighted in Tables 13 and 14.

With regard to the classifications of the library users, opinions of the heads of branch libraries were solicited and are presented in Table 4:

Table 4 indicates that the classification of the library users comprised people from different walks of life. Civil servants formed the largest category of library users, as indicated by $50(98 \%)$ heads of branch libraries, followed by the general category of students and adults within the respective communities as the most common library users. This was

TABLE 4: Opinions of the heads of branch libraries on the classification of the library users $(N=51)$.

\begin{tabular}{|c|c|c|c|c|c|c|c|c|c|c|c|}
\hline \multirow[t]{2}{*}{ Classification of the library users } & \multicolumn{2}{|c|}{ SA } & \multicolumn{2}{|c|}{ A } & \multicolumn{2}{|c|}{ D } & \multicolumn{2}{|c|}{ SD } & \multicolumn{2}{|c|}{ UD } & \multirow[t]{2}{*}{ Mean } \\
\hline & $\mathbf{F}$ & $\%$ & $F$ & $\%$ & $\mathbf{F}$ & $\%$ & $F$ & $\%$ & $F$ & $\%$ & \\
\hline Students & 39 & 76.5 & 10 & 19.6 & - & - & 1 & 2.0 & 1 & 2.0 & 4.7 \\
\hline Subsistence farmers & 13 & 25.5 & 24 & 47.1 & 4 & 7.8 & 6 & 11.8 & 4 & 7.8 & 3.7 \\
\hline Large-scale farmers & 10 & 19.6 & 18 & 35.3 & 6 & 11.8 & 6 & 11.8 & 11 & 21.6 & 3.2 \\
\hline Artisans & 3 & 5.9 & 16 & 31.4 & 4 & 7.8 & 18 & 35.3 & 10 & 19.6 & 2.7 \\
\hline Civil servants & 28 & 54.9 & 22 & 43.1 & - & - & - & - & 1 & 2.0 & 4.5 \\
\hline Non-literate people & 2 & 3.9 & 19 & 37.3 & 6 & 11.8 & 19 & 37.3 & 5 & 9.8 & 2.9 \\
\hline People living in terrain areas & 3 & 5.9 & 14 & 27.5 & 7 & 13.7 & 21 & 41.2 & 6 & 11.8 & 2.7 \\
\hline Adults & 34 & 66.7 & 15 & 29.4 & 1 & 2.0 & - & - & 1 & 2.0 & 4.6 \\
\hline Children & 28 & 54.9 & 19 & 37.3 & - & - & 2 & 3.9 & 2 & 3.9 & 4.4 \\
\hline Housewives & 15 & 29.4 & 14 & 27.5 & 3 & 5.9 & 14 & 27.5 & 5 & 9.8 & 3.4 \\
\hline Unemployed & 23 & 45.1 & 15 & 29.4 & 1 & 2.0 & 7 & 13.7 & 5 & 9.8 & 3.9 \\
\hline Others (teachers, nurses and researchers) & 2 & 3.9 & - & - & - & - & 3 & 5.9 & 46 & 90.2 & 1.2 \\
\hline
\end{tabular}

SA, strongly agree; A, agree; $D$, disagree; SD, strongly disagree; UD, undecided; F, frequency. 
revealed by a total of $49(96.1 \%)$ heads of branch libraries on each, respectively; a total of $47(92.2 \%)$ also indicated that children were next in the ranking, followed by the general category of literate people $(45 ; 88.2 \%)$ and subsistence farmers $(37 ; 72.1 \%)$ as well as housewives along with largescale farmers $(28 ; 54.9 \%)$. Unemployed people (jobless) were also among the library users, as indicated by 38 (74.5\%) heads of branch libraries. This indicates that the unemployed patronised the library services in search of job vacancies. Another reason could be that they might probably patronise the library services for leisure and for current affairs with a view to keeping themselves abreast of day-to-day happenings.

However, the study found that other categories of persons like non-literate people, artisans and people living in terrain areas virtually did not patronise the library services at all, as indicated by a very small number of the heads of branch libraries. This indicates that the forms of information sources and services available in the libraries are not relevant to these categories of persons, which is a challenge to the libraries under study.

\section{Information needs of rural dwellers in the North-West zone of Nigeria}

Among the information needs enquired about were agriculture, health, economy, government policies, education, culture and recreation, and rural development. The opinions of the heads of branch libraries were solicited and scored on a five-point scale (see Table 5).

Table 5 shows that agricultural information needs were wide ranging and related mainly to inputs such as fertiliser, seeds, pesticides, vaccines, feeds, housing, and vitamins and minerals, which topped the agricultural information needs of the rural dwellers. This is reflected in the mean score of 4.6. These needs tended to be consistent with the occupational orientation of the rural people, which is primarily farming. Information needs about farm implements like ploughs, harrows and cultivators were the next with a mean score of 4.5. The needs for information on agricultural machinery (e.g. thrashers, winnowers and harvesters), farming techniques and marketing of agricultural products were basically rated almost the same, with mean scores of 4.2, 4.1 and 3.9, respectively.

With regard to health information needs, Table 6 shows that information relating to infectious diseases (such as HIV and AIDS, TB, hepatitis, malaria, influenza and diarrhoea) and information about routine immunisation were the most outstanding information needs, as identified by the heads of branch libraries, with a mean score of 4.4 . Information on routine immunisation, nutrition, disease or epidemic outbreaks and environmental sanitation were equally ranked with a mean score of 4.0. These were followed by information needs about family planning, with a mean score of 3.8 .

Table 7 shows that information on governance topped the information needs of the rural dwellers on government policies, with a highest mean score of 4.3. This was followed by information on elections and voters' registration and population census, with mean scores of 4.1 and 4.0, respectively; information on government programmes for rural development, with a mean score of 3.9; and information on afforestation, with a mean score of 3.8. Information about deforestation and skills acquisition was ranked the same, with a mean score of 3.7 .

TABLE 5: Opinions of the heads of branch libraries on agricultural information needs of rural dwellers $(N=51)$.

\begin{tabular}{|c|c|c|c|c|c|c|c|c|c|c|c|}
\hline \multirow[t]{2}{*}{ Agricultural information needs } & \multicolumn{2}{|c|}{ SA } & \multicolumn{2}{|c|}{ A } & \multicolumn{2}{|c|}{ D } & \multicolumn{2}{|c|}{ SD } & \multicolumn{2}{|c|}{ UD } & \multirow[t]{2}{*}{ Mean } \\
\hline & $\mathbf{F}$ & $\%$ & $\mathbf{F}$ & $\%$ & $\mathbf{F}$ & $\%$ & $\mathbf{F}$ & $\%$ & $\mathbf{F}$ & $\%$ & \\
\hline Inputs (fertiliser, seeds, pesticide, vaccines, feeds, housing, vitamins and minerals) & 39 & 76.5 & 10 & 19.6 & - & - & - & - & 2 & 3.9 & 4.6 \\
\hline Farm implements (plough, harrow and cultivators) & 31 & 60.8 & 18 & 35.3 & - & - & - & - & 2 & 3.9 & 4.5 \\
\hline Tractors & 30 & 58.8 & 13 & 25.5 & - & - & 4 & 7.8 & 4 & 7.8 & 4.2 \\
\hline Machineries (thrasher, winnower and harvester) & 24 & 47.1 & 20 & 39.2 & 2 & 3.9 & 1 & 2.0 & 4 & 7.8 & 4.2 \\
\hline Farming techniques & 28 & 54.9 & 14 & 27.5 & 3 & 5.9 & 2 & 3.9 & 4 & 7.8 & 4.2 \\
\hline Agricultural loans and credits & 27 & 52.9 & 16 & 31.4 & - & - & 3 & 5.9 & 5 & 9.8 & 4.1 \\
\hline Marketing & 26 & 51.0 & 14 & 27.5 & - & - & 2 & 3.9 & 9 & 17.6 & 3.9 \\
\hline Others & 4 & 7.8 & 4 & 7.8 & - & - & - & - & 43 & 84.3 & 1.5 \\
\hline
\end{tabular}

SA, strongly agree; A, agree; $D$, disagree; SD, strongly disagree; UD, undecided; F, frequency

TABLE 6: Opinions of the heads of branch libraries on health information needs of the rural dwellers $(N=51)$.

\begin{tabular}{|c|c|c|c|c|c|c|c|c|c|c|c|}
\hline \multirow[t]{2}{*}{ Health information (heads of branch libraries) } & \multicolumn{2}{|c|}{ SA } & \multicolumn{2}{|c|}{ A } & \multicolumn{2}{|c|}{ D } & \multicolumn{2}{|c|}{ SD } & \multicolumn{2}{|c|}{ UD } & \multirow[t]{2}{*}{ Mean } \\
\hline & $\mathbf{F}$ & $\%$ & $\mathbf{F}$ & $\%$ & $\mathbf{F}$ & $\%$ & $\mathbf{F}$ & $\%$ & $\mathbf{F}$ & $\%$ & \\
\hline Infectious diseases (HIV and AIDS, TB, hepatitis, malaria, influenza and diarrhoea) & 35 & 68.6 & 10 & 19.6 & 2 & 3.9 & 1 & 2.0 & 3 & 5.9 & 4.4 \\
\hline Maternal and child healthcare & 28 & 54.9 & 19 & 37.3 & - & - & 1 & 2.0 & 3 & 5.9 & 4.3 \\
\hline Routine immunisation & 30 & 58.8 & 17 & 33.3 & 1 & 2.0 & - & - & 3 & 5.9 & 4.4 \\
\hline Nutrition & 25 & 49.0 & 14 & 27.5 & 2 & 3.9 & 6 & 11.8 & 4 & 7.8 & 4.0 \\
\hline Family planning & 19 & 37.3 & 18 & 35.3 & 4 & 7.8 & 4 & 7.8 & 6 & 11.8 & 3.8 \\
\hline Disease/epidemic outbreaks & 18 & 35.3 & 24 & 47.1 & 2 & 3.9 & 3 & 5.9 & 4 & 7.8 & 4.0 \\
\hline Environmental sanitation & 24 & 47.1 & 18 & 35.3 & - & - & 2 & 3.9 & 7 & 13.7 & 4.0 \\
\hline Others & 2 & 3.9 & 1 & 2.0 & - & - & 1 & 2.0 & 47 & 92.2 & 1.2 \\
\hline
\end{tabular}

SA, strongly agree; A, agree; $D$, disagree; SD, strongly disagree; UD, undecided; F, frequency. 
As shown in Table 8, the heads of the branch libraries were of the view that the economic information needed most by the rural dwellers was on youth and women empowerment, with a mean score of 4.5. The information needs by hierarchy according to the heads of branch libraries, apart from the youth and women empowerment, were micro-credit loans and finance, and employment opportunities, with a mean of 4.3 each, while the information need on business/ entrepreneurial skills was ranked the least, with a mean score of 4.2.

Table 9 shows that the rural dwellers needed as much information about tertiary and secondary education as about universal basic education (UBE), with a mean score of 4.4 each. Other educational information needs of almost equal importance were those on adult education (mean score 4.3), girls' education (mean score 4.2) and nomadic education (mean score 4.1 ).

Table 10 shows that information on cultural festivals topped the information needs of rural dwellers, with a mean score of 4.0, followed by entertainment at the second position, with a mean score of 3.7, and tourism and documentaries ranked at the same level, each with a mean score of 3.6.

Table 11 shows that information needs about potable water and modes of transportation ranked as the first priority of rural dwellers, with a mean score of 4.4 , among the areas of rural development mentioned. This was followed by information needs on electrification (mean 4.3), food security (mean 4.3) and accessible road (mean 4.1) along with housing (mean 3.7).

TABLE 7: Opinions of the heads of branch libraries on information needs of the rural dwellers on government policies $(N=51)$.

\begin{tabular}{|c|c|c|c|c|c|c|c|c|c|c|c|}
\hline \multirow[t]{2}{*}{ Government policies as information needs } & \multicolumn{2}{|c|}{ SA } & \multicolumn{2}{|c|}{ A } & \multicolumn{2}{|c|}{ D } & \multicolumn{2}{|c|}{ SD } & \multicolumn{2}{|c|}{ UD } & \multirow[t]{2}{*}{ Mean } \\
\hline & $\mathbf{F}$ & $\%$ & $\mathbf{F}$ & $\%$ & $\mathbf{F}$ & $\%$ & $\mathbf{F}$ & $\%$ & $\mathbf{F}$ & $\%$ & \\
\hline Governance & 30 & 58.8 & 16 & 31.4 & - & - & 2 & 3.9 & 3 & 5.9 & 4.3 \\
\hline Elections and voters' registration & 18 & 35.3 & 29 & 56.9 & - & - & 1 & 2.0 & 3 & 5.9 & 4.1 \\
\hline Population census & 22 & 43.1 & 21 & 41.2 & 1 & 2.0 & 2 & 3.9 & 5 & 9.8 & 4.0 \\
\hline Afforestation & 17 & 33.3 & 22 & 43.1 & 2 & 3.9 & 4 & 7.8 & 6 & 11.8 & 3.8 \\
\hline Deforestation & 14 & 27.5 & 23 & 45.1 & 3 & 5.9 & 7 & 13.7 & 4 & 7.8 & 3.7 \\
\hline Skills acquisition & 18 & 35.3 & 20 & 39.2 & - & - & 4 & 7.8 & 9 & 17.6 & 3.7 \\
\hline Government programmes (rural development) & 21 & 41.2 & 21 & 41.2 & 1 & 2.0 & 1 & 2.0 & 7 & 13.7 & 3.9 \\
\hline Others & 1 & 2.0 & 2 & 3.9 & - & - & - & - & 48 & 94.1 & 1.2 \\
\hline
\end{tabular}

SA, strongly agree; A, agree; D, disagree; SD, strongly disagree; UD, undecided; F, frequency.

TABLE 8: Opinions of the heads of branch libraries on economic information needs of the rural dwellers $(N=51)$.

\begin{tabular}{|c|c|c|c|c|c|c|c|c|c|c|c|}
\hline \multirow[t]{2}{*}{ Economic information needs } & \multicolumn{2}{|c|}{ SA } & \multicolumn{2}{|c|}{ A } & \multicolumn{2}{|c|}{ D } & \multicolumn{2}{|c|}{ SD } & \multicolumn{2}{|c|}{ UD } & \multirow[t]{2}{*}{ Mean } \\
\hline & $\mathbf{F}$ & $\%$ & $\mathbf{F}$ & $\%$ & $\mathbf{F}$ & $\%$ & $\mathbf{F}$ & $\%$ & $\mathbf{F}$ & $\%$ & \\
\hline Micro-credit loans and finance & 30 & 58.8 & 16 & 31.4 & - & - & 1 & 2.0 & 4 & 7.8 & 4.3 \\
\hline Business/entrepreneurial skills & 26 & 51.0 & 18 & 35.3 & 1 & 2.0 & 2 & 3.9 & 4 & 7.8 & 4.2 \\
\hline Youth and women empowerment & 32 & 62.7 & 17 & 33.3 & - & - & - & - & 2 & 3.9 & 4.5 \\
\hline Employment opportunities & 29 & 56.9 & 14 & 27.5 & 3 & 5.9 & 2 & 3.9 & 3 & 5.9 & 4.3 \\
\hline Others & 6 & 11.8 & 1 & 2.0 & - & - & - & - & 44 & 86.3 & 1.5 \\
\hline
\end{tabular}

$\mathrm{SA}$, strongly agree; $\mathrm{A}$, agree; $\mathrm{D}$, disagree; $\mathrm{SD}$, strongly disagree; $\mathrm{UD}$, undecided; $F$, frequency.

TABLE 9: Opinions of the heads of branch libraries on educational information needs of the rural dwellers $(N=51)$

\begin{tabular}{|c|c|c|c|c|c|c|c|c|c|c|c|}
\hline \multirow[t]{2}{*}{ Educational information needs } & \multicolumn{2}{|c|}{ SA } & \multicolumn{2}{|c|}{$A$} & \multicolumn{2}{|c|}{$\bar{D}$} & \multicolumn{2}{|c|}{ SD } & \multicolumn{2}{|c|}{ UD } & \multirow[t]{2}{*}{ Mean } \\
\hline & $F$ & $\%$ & $F$ & $\%$ & $\mathbf{F}$ & $\%$ & $\mathbf{F}$ & $\%$ & $F$ & $\%$ & \\
\hline Tertiary education & 31 & 60.8 & 15 & 29.4 & 1 & 2.0 & 1 & 2.0 & 3 & 5.9 & 4.4 \\
\hline Secondary education & 29 & 56.9 & 17 & 33.3 & 2 & 3.9 & - & - & 3 & 5.9 & 4.4 \\
\hline Universal basic education (UBE) & 32 & 62.7 & 14 & 27.5 & 1 & 2.0 & 1 & 2.0 & 3 & 5.9 & 4.4 \\
\hline Adult education & 28 & 54.9 & 17 & 33.3 & 2 & 3.9 & 1 & 2.0 & 3 & 5.9 & 4.3 \\
\hline Girl-child education & 25 & 49.0 & 20 & 39.2 & 1 & 2.0 & - & - & 5 & 9.8 & 4.2 \\
\hline Nomadic education & 21 & 41.2 & 22 & 43.1 & 3 & 5.9 & 1 & 2.0 & 4 & 7.8 & 4.1 \\
\hline Others & 3 & 5.9 & - & - & - & - & - & - & 48 & 94.1 & 1.2 \\
\hline
\end{tabular}

$\mathrm{SA}$, strongly agree; $\mathrm{A}$, agree; $\mathrm{D}$, disagree; $\mathrm{SD}$, strongly disagree; $\mathrm{UD}$, undecided; F, frequency.

TABLE 10: Opinions of the heads of branch libraries on culture and recreational information needs of the rural dwellers $(N=51)$.

\begin{tabular}{|c|c|c|c|c|c|c|c|c|c|c|c|}
\hline \multirow[t]{2}{*}{ Information needs on culture and recreation } & \multicolumn{2}{|c|}{ SA } & \multicolumn{2}{|c|}{ A } & \multicolumn{2}{|c|}{$\mathbf{D}$} & \multicolumn{2}{|c|}{ SD } & \multicolumn{2}{|c|}{ UD } & \multirow[t]{2}{*}{ Mean } \\
\hline & $\mathbf{F}$ & $\%$ & $\mathbf{F}$ & $\%$ & $\mathbf{F}$ & $\%$ & $\mathbf{F}$ & $\%$ & $\mathbf{F}$ & $\%$ & \\
\hline Cultural festivals & 18 & 35.3 & 24 & 47.1 & 2 & 3.9 & 4 & 7.8 & 3 & 5.9 & 4.0 \\
\hline Tourism & 11 & 21.6 & 26 & 51.0 & 1 & 2.0 & 9 & 17.6 & 4 & 7.8 & 3.6 \\
\hline Documentaries & 11 & 21.6 & 27 & 52.9 & 2 & 3.9 & 4 & 7.8 & 7 & 13.7 & 3.6 \\
\hline Entertainment & 12 & 23.5 & 25 & 49.0 & 2 & 3.9 & 9 & 17.6 & 3 & 5.9 & 3.7 \\
\hline Others & 2 & 3.9 & 1 & 2.0 & 1 & 2.0 & - & - & 47 & 92.2 & 1.3 \\
\hline
\end{tabular}

SA, strongly agree; A, agree; $D$, disagree; SD, strongly disagree; UD, undecided; F, frequency. 
TABLE 11: Opinions of the heads of branch libraries on the information needs of the rural dwellers on rural development programmes $(N=51)$.

\begin{tabular}{|c|c|c|c|c|c|c|c|c|c|c|c|}
\hline \multirow[t]{2}{*}{ Information needs on rural development } & \multicolumn{2}{|c|}{ SA } & \multicolumn{2}{|c|}{ A } & \multicolumn{2}{|c|}{ D } & \multicolumn{2}{|c|}{ SD } & \multicolumn{2}{|c|}{ UD } & \multirow[t]{2}{*}{ Mean } \\
\hline & $F$ & $\%$ & $\mathbf{F}$ & $\%$ & $\mathbf{F}$ & $\%$ & $F$ & $\%$ & $F$ & $\%$ & \\
\hline Potable water & 35 & 68.6 & 9 & 17.6 & 4 & 7.8 & - & - & 3 & 5.9 & 4.4 \\
\hline Rural electricity & 29 & 56.9 & 15 & 29.4 & 2 & 3.9 & 2 & 3.9 & 3 & 5.9 & 4.3 \\
\hline Food security & 27 & 52.9 & 18 & 35.3 & 2 & 3.9 & 2 & 3.9 & 2 & 3.9 & 4.3 \\
\hline Mode of transport (bus, car, vans, lorries, motorcycle, bicycle, etc.) & 24 & 47.1 & 23 & 45.1 & 3 & 5.9 & - & - & 1 & 2.0 & 4.4 \\
\hline Accessible road & 19 & 37.3 & 24 & 47.1 & 4 & 7.8 & 1 & 2.0 & 3 & 5.9 & 4.1 \\
\hline Housing & 17 & 33.3 & 18 & 35.3 & 5 & 9.8 & 5 & 9.8 & 6 & 11.8 & 3.7 \\
\hline Others & - & - & - & - & 1 & 2.0 & - & - & 50 & 98.0 & 1.0 \\
\hline
\end{tabular}

$S A$, strongly agree; $A$, agree; $D$, disagree; $S D$, strongly disagree; $U D$, undecided; $F$, frequency.

\section{Extent of utilisation of information sources and services among rural dwellers from public libraries in the North-West zone of Nigeria}

Opinions of the library users as rural dwellers were solicited on the extent to which the information sources and services were utilised from public libraries in the North-West zone of Nigeria. Table 12 presents the extent of utilisation in frequencies and percentages.

Table 12 shows that the majority of library users as rural dwellers used information sources and services available in the libraries on a daily basis. The data indicate that $105(31.6 \%)$ library users utilised the information sources and services on a daily basis and $88(26.5 \%)$ on a weekly basis. The information sources and services were almost utilised by equal numbers of library users on a monthly and bi-monthly basis. Table 12 shows that $75(22.6 \%)$ of the library users utilised the information sources and services on a monthly basis, while 64 (19.3\%) used them on a bi-monthly basis.

\section{Forms of information sources and services utilised among rural dwellers from public libraries in the zone under study}

Opinions about the information sources and services available from public libraries were solicited from the library users and heads of the branch libraries. Table 13 shows the responses of the library users on the available information sources they utilised from the libraries.

It is clear from the responses in Table 13 that a total of $79.8 \%$ (186; $56.0 \%$ and $79 ; 23.8 \%$ ) of the library users strongly agreed and agreed, respectively, that printed materials (such as books, journals, newspapers and magazines) were the most frequently utilised information sources among rural dwellers from public libraries. This is reflected in a highest mean score of 4.2. This was attributed to the fact that the majority of people who patronised the libraries were the literate people among the rural dwellers. The perceptions of the library users also indicate that posters and flyers as information sources were rated second in the hierarchy. The data reveal that $64.2 \%(74 ; 22.3 \%$ and 139 ; $41.9 \%$ ) of the participants strongly agreed and agreed, respectively, that they also utilised these forms of information sources from public libraries. This is reflected in a mean score of 3.5. Other information sources utilised among rural dwellers from the libraries were audiovisuals. The responses show that $56.3 \%(79 ; 23.8 \%$ and $108 ; 32.5 \%)$ of
TABLE 12: Opinions of the library users on the extent of utilisation of information sources and services among rural dwellers from the libraries $(N=332)$.

\begin{tabular}{llcc}
\hline $\mathbf{S} / \mathbf{N}$ & $\begin{array}{l}\text { To what extent do you use the information } \\
\text { sources and services in the library? }\end{array}$ & Frequency & $\mathbf{\%}$ \\
\hline 1 & Monthly & 75 & 22.6 \\
\hline 2 & Bi-monthly & 64 & 19.28 \\
3 & Weekly & 88 & 26.5 \\
\hline 4 & Daily & 105 & 31.6 \\
\hline 5 & Others & Nil & Nil \\
\hline & Total & $\mathbf{3 3 2}$ & $\mathbf{1 0 0}$ \\
\hline S/N
\end{tabular}

the participants strongly agreed and agreed, respectively, that audiovisual facilities were utilised from public libraries. This is reflected in a mean score of 3.4.

However, participant responses show that a total of $70.8 \%$ (73; $22.0 \%$ and $162 ; 48.8 \%$ ) of the library users strongly disagreed and disagreed, respectively, that they utilised gatekeepers as information sources from the libraries (Table 13). This is reflected in a mean score of 2.6. Likewise, the responses show that $65.1 \%(67 ; 20.2 \%$ and $149 ; 44.9 \%)$ of the participants strongly disagreed and disagreed, respectively, that they utilised village extension workers (VEWs) and community health extension workers (CHEWs) as information sources from the libraries (Table 13). This is reflected in a mean score of 2.7. Similarly, participant responses indicate that $60.6 \%$ $(74 ; 22.3 \%$ and $127 ; 38.3 \%)$ of the participants strongly disagreed and disagreed, respectively, that they utilised community information resource centres as information sources from public libraries (Table 13). This is reflected in a mean score of 2.9. The responses also show that $64.7 \%$ $(108 ; 32.5 \%$ and $107 ; 32.2 \%)$ of the participants strongly disagreed and disagreed, respectively, that they utilised town criers as information sources from public libraries (Table 13). This is reflected in a mean score of 2.9.

The total frequencies and percentages indicate that the library users did not utilise viewing centres as information sources from the libraries (Table 13). The data indicate that $56.1 \%(61 ; 18.4 \%$ and $125 ; 37.7 \%)$ of the participants strongly disagreed and disagreed, respectively, that they utilised viewing centres from public libraries (Table 13). The high percentage of no use was because of the unavailability of the service. The viewing centres are places where facilities such as television, TV programmes, videos, projectors and films are provided for educating, enlightening and entertaining people in rural areas. Likewise, the data reveal that $46.7 \%(43 ; 13.0 \%$ and $112 ; 33.7 \%)$ of the library users 
Table 13: Opinions of the library users on the forms of information sources utilised among rural dwellers from public libraries $(N=332)$.

\begin{tabular}{|c|c|c|c|c|c|c|c|c|c|c|c|}
\hline \multirow[t]{2}{*}{ Information sources utilised among the rural dwellers } & \multicolumn{2}{|c|}{ SA } & \multicolumn{2}{|c|}{ A } & \multicolumn{2}{|c|}{ D } & \multicolumn{2}{|c|}{ SD } & \multicolumn{2}{|c|}{ UD } & \multirow[t]{2}{*}{ Mean } \\
\hline & $\mathbf{F}$ & $\%$ & $\mathbf{F}$ & $\%$ & $\mathbf{F}$ & $\%$ & $\mathbf{F}$ & $\%$ & $\mathbf{F}$ & $\%$ & \\
\hline Printed materials (books, journals, newspapers and magazines) & 186 & 56.0 & 79 & 23.8 & 26 & 7.8 & 14 & 4.2 & 27 & 8.1 & 4.2 \\
\hline Town criers as a source from the library & 37 & 11.1 & 55 & 16.6 & 108 & 32.5 & 107 & 32.2 & 25 & 7.5 & 2.9 \\
\hline Gatekeepers as a source from the library & 38 & 11.4 & 26 & 7.8 & 73 & 22.0 & 162 & 48.8 & 33 & 9.9 & 2.6 \\
\hline Extension workers (VEWs and CHEWs) as a source from the library & 31 & 9.3 & 51 & 15.4 & 67 & 20.2 & 149 & 44.9 & 34 & 10.2 & 2.7 \\
\hline Viewing centres & 41 & 12.3 & 81 & 24.4 & 61 & 18.4 & 125 & 37.7 & 24 & 7.2 & 3.0 \\
\hline Community information resource centres & 46 & 13.9 & 59 & 17.8 & 74 & 22.3 & 127 & 38.3 & 26 & 7.8 & 2.9 \\
\hline Audiovisuals & 79 & 23.8 & 108 & 32.5 & 38 & 11.4 & 81 & 24.4 & 26 & 7.8 & 3.4 \\
\hline Posters and fliers & 74 & 22.3 & 139 & 41.9 & 32 & 9.6 & 61 & 18.4 & 26 & 7.8 & 3.5 \\
\hline ICTs (e.g. computers and Internet facility) & 43 & 13.0 & 58 & 17.5 & 43 & 13.0 & 112 & 33.7 & 76 & 22.9 & 2.6 \\
\hline Others & 67 & 20.2 & 44 & 13.3 & 12 & 3.6 & 15 & 4.5 & 194 & 58.4 & 2.3 \\
\hline
\end{tabular}

Others

SA, strongly agree; A, agree; D, disagree; SD, strongly disagree; UD, undecided; F, frequency, VEWs, village extension workers; CHEWs, community health extension workers; ICTs, information and communication technologies.

TABLE 14: Opinions of the heads of branch libraries on the forms of information services provided by public libraries to rural dwellers $(N=51)$.

\begin{tabular}{|c|c|c|c|c|c|c|c|c|c|c|c|}
\hline \multirow[t]{2}{*}{ Does your library provide these services to rural dwellers? } & \multicolumn{2}{|c|}{ SA } & \multicolumn{2}{|c|}{ A } & \multicolumn{2}{|c|}{ D } & \multicolumn{2}{|c|}{ SD } & \multicolumn{2}{|c|}{ UD } & \multirow[t]{2}{*}{ Mean } \\
\hline & $\mathbf{F}$ & $\%$ & $\mathbf{F}$ & $\%$ & $\mathbf{F}$ & $\%$ & $\mathbf{F}$ & $\%$ & $\mathbf{F}$ & $\%$ & \\
\hline $\begin{array}{l}\text { Traditional services (reference services, circulation services, lending } \\
\text { services, serial services, children services, etc.) }\end{array}$ & 36 & 70.6 & 10 & 19.6 & 2 & 3.9 & 2 & 3.9 & 1 & 2.0 & 4.5 \\
\hline Mobile library services & 2 & 3.9 & 4 & 7.8 & 23 & 45.1 & 19 & 37.3 & 3 & 5.9 & 2.7 \\
\hline Information repackaging & 3 & 5.9 & 9 & 17.6 & 20 & 39.2 & 14 & 27.5 & 5 & 9.8 & 2.8 \\
\hline Awareness campaigns on government policies & 8 & 15.7 & 19 & 37.3 & 12 & 23.5 & 9 & 17.6 & 3 & 5.9 & 3.4 \\
\hline Translation services & 5 & 9.8 & 8 & 15.7 & 24 & 47.1 & 9 & 17.6 & 5 & 9.8 & 3.0 \\
\hline $\begin{array}{l}\text { Organising meetings, workshops, seminars, and exhibitions for rural } \\
\text { dwellers to enhance their living conditions }\end{array}$ & 10 & 19.6 & 12 & 23.5 & 14 & 27.5 & 11 & 21.6 & 4 & 7.8 & 3.3 \\
\hline Adult literacy programmes & 8 & 15.7 & 16 & 31.4 & 16 & 31.4 & 9 & 17.6 & 2 & 3.9 & 3.4 \\
\hline Others & - & - & 2 & 3.9 & - & - & - & - & 49 & 96.1 & 1.1 \\
\hline
\end{tabular}

SA, strongly agree; $A$, agree; $D$, disagree; $S D$, strongly disagree; UD, undecided; F, frequency.

strongly disagreed and disagreed, respectively, that they utilised ICTs (such as computers and Internet facility) as information sources from public libraries to satisfy their information needs (Table 13). This is reflected in a mean score of 2.6 (Table 13). The data show that only $30.5 \%$ (43; $13.0 \%$ and $58 ; 17.5 \%)$ of the participants strongly agreed and agreed, respectively, that they utilised such sources from the libraries, while $76(22.9 \%)$ of participants remained undecided (Table 13). The opinions of the heads of branch libraries on the forms of information services provided by public libraries to rural dwellers in the North-West zone of Nigeria are presented in Table 14.

From Table 14, it is clear that the services provided by public libraries to rural dwellers in the North-West zone of Nigeria were mostly traditional library services, which included reference services, circulation services, lending services, serial services and services for children. This is reflected in a mean score of 4.5 . The responses show that $90.2 \%$ (36; 70.6\% and $10 ; 19.6 \%$ ) of the participants strongly agreed and agreed, respectively, that such services were provided by the libraries. The second item in the hierarchy was the provision of awareness campaigns on government policies. The responses show that $53 \%(8 ; 15.7 \%$ and $19 ; 37.3 \%)$ of the participants strongly agreed and agreed, respectively, that such information service was provided by the libraries. This is reflected in a mean score of 3.4 .

However, the heads of branch libraries revealed that mobile library services and information repackaging were not provided by the libraries to rural dwellers (Table 14).
The responses show that $82.4 \%(23 ; 45.1 \%$ and $19 ; 37.3 \%)$ of the participants strongly disagreed and disagreed, respectively, that mobile library services were provided to rural dwellers, as reflected in a mean score of 2.7. Likewise, the responses show that $66.7 \%(20 ; 39.2 \%$ and $14 ; 27.5 \%)$ of the participants strongly disagreed and disagreed, respectively, that information repackaging services were provided by the libraries to rural dwellers (Table 14). The data also indicate that the libraries did not organise meetings, workshops, seminars and exhibitions as information services for rural dwellers, as revealed by $49.1 \%(14 ; 27.5 \%$ and $11 ; 21.6 \%)$ participants who strongly disagreed and disagreed, respectively, that such services were provided. Likewise, the responses reveal that $64.7 \%(24 ; 47.1 \%$ and $9 ; 17.6 \%)$ of the participants strongly disagreed and disagreed, respectively, that translation services were provided by public libraries for the rural dwellers (Table 14). Similarly, the responses indicate that $49 \%(16 ; 31.4 \%$ and $9 ; 17.6 \%)$ of the participants strongly disagreed and disagreed, respectively, that the libraries under study provided adult literacy programmes as information service (Table 14). From the responses, it is clear that only $47.1 \%(8 ; 15.7 \%$ and $16 ; 31.4 \%)$ of the participants strongly agreed and agreed, respectively, that such service was provided by the libraries, while two (3.9\%) participants remained undecided (Table 14).

\section{Ethical consideration}

Ethical clearance was obtained from the Humanities and Social Sciences Research Ethics Committee of the University of KwaZulu-Natal (Reference number: HSS/0808/017D). 


\section{Discussion and interpretation of results \\ Information needs of rural dwellers in the North-West zone of Nigeria}

Generally, from the expressed opinions of the heads of branch libraries, it is clear that the rural dwellers were in need of information for sustainable rural development, especially on agriculture, education, economy, government policies, health-related issues, culture and recreation, as well as rural development. Public libraries are therefore expected to provide relevant and effective information resources and services that can meet the information needs of rural dwellers in these areas for sustainable rural development. These findings were consistent with those of Ape (2012), Emmanuel (2012), Momodu (2012), Udofia (2012), Daudu and Mohammed (2013), Mtega and Ronald (2013), IdiegbeyanOse et al. (2015), Patience (2015) and Ezema (2016).

\section{Forms of information sources utilised among rural dwellers from public libraries in the North-West zone of Nigeria}

From the findings of this study, it is evident that the forms of information sources utilised among the rural dwellers from the libraries were mainly printed materials, such as books, journals, newspapers and magazines. This confirms the reason why the majority of people who patronised the libraries were relatively literate people among the rural dwellers. It also confirms the reason why the libraries were patronised by few non-literate people (as shown in Table 3). Other information sources utilised by rural dwellers from the public libraries, as confirmed by most of the library users, were posters and flyers as well as audiovisuals. Most libraries did not have access to online information. These findings support those of Anyalebechi and Udo-Anyanwu (2016) in their research on public libraries in Nigeria, who found that the information sources available in the libraries for the users were more or less textbooks, reference materials, serials or journals, audiovisuals, government publications, electronic information sources and foreign publication. Correa et al. (1997:8) noted that the most effective means of communicating information to rural communities were audiovisual media, such as radio, audio cassettes and films.

Notable from the findings also was the unavailability of other formal places like community information resource centres and viewing centres. As suggested by Aina (2006) and Kamba (2009), these places were supposed to be established by public libraries in rural communities for the extension of library services in the remote rural villages. Likewise, the study did not find that other information sources such as town criers, extension workers, and gatekeepers were available and utilised among rural dwellers from the libraries. The non-literate rural dwellers are more familiar with oral information sources because of their literacy level. Tabor (2009:2) confirmed that rural people are accustomed to oral tradition and can better relate to information exchanged in the way they understand. This shows that public libraries in the area under study did not incorporate oral information sources and other formal places which are unique to the needs of rural dwellers. Similarly, ICT facilities as information sources were also unavailable in the libraries. This was indicated by about half $(46.7 \%)$ of the library users, while only $30.5 \%$ agreed in that respect and $22.9 \%$ remained undecided.

\section{Forms of information services provided by public libraries to rural dwellers in the zone under study}

In Nigeria, studies by Omopupa (2006), Ebiwolate (2010), Saleh and Lasisi (2011), Enemute and Okorodudu (2012), Oyeronke (2012), Akinola et al. (2013), Chinwe et al. (2014), Joy and Idowu (2014) and Obasi (2015) found that public library and information services generally revolve around community information services, reference services, storytelling services, film show services, reading competition services, career information services, photocopying services, opening hours, online Internet services, lending services, reference services, photocopy services, indexing and abstracting services and bibliographic services. Other services include telephone, recreational and advisory services, current awareness, selective dissemination of information, bookmobiles, referral services, children/school services, computers/Internet/ICT, translation services, user education, outreach and extension programmes, adult literacy programmes, consultancy services, audiovisual services, and packaging and repackaging of information services, among others.

The current study found that the predominant information services provided by public libraries to rural dwellers in the North-West zone of Nigeria were traditional services, which included reference services, circulation services, lending services, serials services and services for children, as well as awareness campaigns on government policies, as confirmed by the majority of heads of branch libraries. These findings concurred with those of Ngcobo (2005) who carried out a research on the role of community libraries in enhancing education in South Africa. The study found that the library services available for the library users included lending services, reference services, audiovisuals and organising debates among school-going children, facilitating adult basic education and training programmes for the adults. Other services included education, entertainment, relaxation and awareness of various issues. Likewise, Akinola et al. (2013) in their research, which focused on public libraries in meeting the information needs of post-secondary students in Nigeria, found that the services available in those libraries were lending and reference services. The results showed that most $(118 ; 81.4 \%)$ of the respondents indicated that the libraries provide lending services, while 108 (74.5\%) of the respondents reported that the libraries provide reference services.

However, based on the findings of this study, it can be said that the libraries under study did not provide adult literacy programmes; neither did they organise meetings, workshops, seminars and exhibitions nor did they provide 
translation services or mobile library services and information repackaging to rural dwellers. These are the kinds of information services that public libraries should provide in rural communities, as suggested by many studies such as those of Iwe (2003), Omopupa (2006), Oyeronke (2012) and Abdullahi (2009).

\section{Recommendations}

Public libraries should be adequately funded to provide sufficient and relevant information sources, particularly the oral information sources that are more familiar to non-literate rural dwellers for sustainable rural development.

Innovative services which are unique to the information needs of rural dwellers should be provided by the libraries. Services such as organising meetings, lectures, seminars or workshops, translation services, information repackaging, mobile library services as well as adult and information literacy programmes should be provided by public libraries for sustainable rural development.

Community information resource centres and viewing centres should be established in rural communities to provide relevant information sources and services to rural dwellers in various formats and languages they understand, as suggested by Aina (2006) and Kamba (2009). These centres should be well equipped with effective and efficient audiovisual facilities such as television, TV programmes, videos, projectors and films for educating, enlightening and entertaining people in rural areas for sustainable rural development.

\section{Conclusion}

This study provided an insight that most of the rural dwellers who utilised the information sources and services were literate people, as the majority of non-literate people did not patronise the libraries under study (as shown in Table 3). This was because of the fact that the major information sources provided in the libraries were printed materials, which included books, journals, newspapers and magazines. Although other information sources such as posters and flyers and audiovisuals were also available, the libraries did not provide information services unique to the literacy levels of the majority of rural dwellers. It is evident that oral information sources, which the non-literate people are more familiar with, were not available from the libraries. In an ideal situation, Aina (2006) and Tabor (2009) are of the opinion that public libraries are supposed to engage the services of town criers, extension workers and gatekeepers in providing relevant information sources to rural dwellers. Formal places such as community information resource centres and viewing centres are supposed to be established in rural communities for the extension of information sources and services to remote rural villages (Aina 2006).

With the exception of awareness campaigns on government policies, the information services provided were more or less traditional library services, such as reference, lending and circulation services and services for children, which were only relevant to literate persons. In a typical rural setting where non-literate people are the majority (Aina 2006), only innovative library services such as organising meetings, seminars and workshops on how to improve the living condition of rural dwellers will not only attract non-literate people but also make the services unique for sustainable rural development, as established by Kamba (2009). Other information services such as adult literacy programmes, information repackaging, translation services and mobile library services should be provided by the libraries.

\section{Acknowledgements}

The authors wish to acknowledge the support of and sponsorship from the authorities of the University of KwaZulu-Natal, South Africa, and Umaru Musa Yar'adua University, Katsina, Nigeria. They appreciate the contributions of Dr Rosemary Kuhn of Cecil Renaud Library, University of KwaZulu-Natal, Pietermaritzburg Campus, South Africa. They would like to thank the authorities of public libraries studied for granting them the permission to carry out the study and the participants for participating in the study.

\section{Competing interests}

The authors declare that they have no financial or personal relationship(s) which may have inappropriately influenced them in writing this article. The views and opinions expressed in this article are those of the authors and do not necessarily reflect the official policy or position of the institutions (funders).

\section{Author's contributions}

B.B.M. was the research leader and participated in designing the research questions, methodology used, literature review, data collection, codification and analysis, and writing of the manuscript. F.G. participated in designing the research question, literature review, methodology used, data analysis and manuscript editing.

\section{References}

Abbas, S.A., 2009, 'How will research be done? Methodology', in D.A. Maiwada \& M.I. Yakasai (eds.), Essentials of educational research proposal writing, pp. 73-91, A.B.U. Press Limited, Zaria.

Abdullahi, I., 2009, 'Introduction', in I. Abdullahi (ed.), Global library and information science: A textbook for students and educators. With Contributions from Africa, Asia, Australia, New Zealand, Europe, Latin America and the Caribbean, the Middle East, and North America, pp. 11-12, IFLA, Hague.

Aina, L.O., 2006, 'Information provision to farmers in Africa: The Library-Extension service linkage', Paper presented at the World Library and Information Congress: 72nd IFLA General Conference and Council held in Seoul, 20-24 August.

Akinola, J.O., Apotiade, J.K., Ogunmodede, T.A. \& Oyetola, S.O., 2013, 'Survey of the services of public libraries in meeting the information needs of post-secondary school students in some three selected public libraries in Nigeria', Greener Journal of Internet, Information and Communication Systems 1(1), 1-12, viewed 15 March 2017, from http://www.gjournals.org/JIICS/archive/vol-11january-2013/akinolaet-al.html.

Anie, S.O., 2014, 'Improving public library services for rural development: information impact', Journal of Information and Knowledge Management 5(2), 203-210, viewed 01 June 2017, from https://www.ajol.info/index.php/iijikm/article/ view/144659/134310.

Annune, A.E., Ezeani, C.N. \& Okafor, V.N., 2014, 'Information sources, dissemination and utilization patterns of the artisanal fishery sector in Benue State, Nigeria', Advances in Research 2(12), 89-905. https://doi.org/10.9734/AIR/2014/9588 
Anyalebechi, L.I. \& Udo-Anyanwu, A.J., 2016, 'Public library services and the attainment of the social wellbeing of users in Enugu state', Journal of Policy and Development Studies 10(1), 37-47, viewed 25 March 2017, from http://www. arabianjbmr.com/pdfs/JPDS_VOL_10_1/4.pdf.

Anyanwu, E.U., 2008, Fundamentals of library and information science, Springfield Publishers Limited, New Owerri.

Ape, R., 2012, 'Meeting information needs of people living HIV and AIDS through public library services in Benue state', Unpublished PhD thesis, Department of Library and Information Science, University of Nigeria, Nsukka.

Bachhav, N.B., 2012, 'Information needs of the rural farmers: A study from Maharashtra, India: A survey', Library Philosophy and Practice (e-Journal) 866, n.p., viewed 28 April 2017, from http://digitalcommons.unl.edu/cgi/viewcontent. cgi?article $=2043 \&$ context $=$ libphilprac.

Chinwe, M., Ogbonna, U.A. \& Osuchukwu, N.P., 2014, 'Information needs of rura dwellers as a measure of the effectiveness of library and information services provision in Anambra state, Nigeria', Journal of Applied Information Science and Technology 7(1), 34-45.

Correa, A.F., Mchombu, K.J., Rodriguez, G.M., Diana, R. \& Yapa, N.U., 1997, Rural information provision in developing countries: Measuring performance and impact, UNESCO, New York.

Daudu, H.M. \& Mohammed, Z., 2013, 'Information dissemination, access and utilization for socio-economic empowerment of rural people in northern states of Nigeria', Annals of Library and Information Studies 60, 235-241, viewed 21 March 2017, from http://nopr.niscair.res.in/bitstream/123456789/26270/1/ALIS\%20 60(4)\%20235-241.pdf

Ebiwolate, P.B., 2010, 'Nigerian public library service to rural areas: Libraries in Nige Delta states', Library Philosophy and Practice 365, 1-5, viewed 11 July 2016, from http://digitalcommons.unl.edu/cgi/viewcontent.cgi?article=1380\&context=libph lprac.

Ejedafiru, E.F., 2015, 'Developing rural libraries and the need for virtual libraries in Nigeria: Threats and opportunities', Developing Country Studies [Online] 5(7) 48-52, viewed 13 June 2016, from http://iiste.org/Journals/index.php/DCS/ article/view/21314/

Emmanuel, H., 2012, 'Information needs and information seeking behaviour of rural farmers in Okpokwu local government area of Benue state of Nigeria', Unpublished project (MLS), University of Nigeria, Nsukka, viewed 22 March 2017, from http://www.unn.edu.ng/publications/files/images/HELEN\% 20EMMANUEL.pdf.

Enemute, B.I. \& Okorodudu, P.O., 2012, 'Public library information resources, facilities and services: User satisfaction with the Edo State Central Library, Benin City, Nigeria', Library Philosophy and Practice 747, n.p., viewed 07 June 2016, from http://digitalcommons.unl.edu/libphilprac/747/.

Ezema, I.J., 2016, 'Reproductive health information needs and access among rural women in Nigeria: A study of Nsukka zone in Enugu state', African Journal of Information and Communication 18, 117-133, viewed 12 April 2017, from http:// wiredspace.wits.ac.za/handle/10539/21788

Food and Agriculture Organization, 2006, The framework for effective rura communication for development, FAO, Rome, viewed 30 April 2017, from http:// www.fao.org/nr/com/gtzworkshop/a0892e00.pdf

Hildreth, S., 2007, 'Rural libraries: The heart of our communities', Public Libraries $46(2), 7-11$.

Idiegbeyan-Ose, J., Adekunjo, O., Ilo, P. \& Odion, F., 2015, 'Availability of library and information services for rural community development in Nigeria: A case study of Ewatto, in Esan South-East LGA of Edo state', Evidence Based Library and Information Science Practice 10(4), 143-155, viewed 08 March 2017, from https://journals.library.ualberta.ca/eblip/index.php/EBLIP/article/view/2402.

Ifukor, M.O., 2013, 'Channels of information acquisition and dissemination among rural dwellers', International Journal of Library and Information Science 5(10), 306-312, viewed 21 March 2017, from http://www.academicjournals.org/ journal/IJLIS/article-full-text-pdf/494E19F40088

Islam, M.S., 2006, 'Status of rural library and information services in Bangladesh: Direction for the development', The Social Sciences 1(1), 15-21, viewed 28 April 2017, from http://docsdrive.com/pdfs/medwelljournals/sscience/2006/ 15-21.pdf.

Iwe, J.I., 2003, 'Libraries and information in sustainable rural development in Nigeria', Information Development 19(3), 169-177. https://doi.org/10.1177/026666690 3193004

Iwhiwhu, B.E. \& Okorodudu, P.O., 2012, 'Public library information resources, facilities, and services: User satisfaction with the Edo State central library, Benin-city, Nigeria', Library Philosophy and Practice 747, 1-15, viewed 20 March 2017, from http://digitalcommons.unl.edu/libphilprac/747/.

Jiyane, G.V., 2002, 'An exploratory study of the information availability and utilization by the rural women of Melmoth, KwaZulu-Natal', Unpublished thesis (Master of Library and Information Science), University of Zululand, Kwa Dlangezwa.

Joy, I.I. \& Idowu, A.I., 2014, 'Utilization and user satisfaction of public library services in South-West, Nigeria in the 21st century: A survey', International Journal of Library Science 3(1), 1-6, viewed 18 June 2016, from http://article.sapub.org/10. 5923.j.library.20140301.01.html

Kamba, M.A., 2009, Access to information: The dilemma for rural community development in Africa, viewed 15 June 2016, from https://aragorn.library.gatech. edu/handle/1853/36694]

Krejcie, R.V. \& Morgan, D.W., 1970, 'Determining sample size for research activities', Educational and Psychological Measurement 30, 607-610. https://doi.org/ $10.1177 / 001316447003000308$
Maepa, M.E., 2000, 'Information needs and information-seeking patterns of rura people in the Northern Province', Unpublished thesis (D. Litt et Phil.), Faculty of Arts, Rand Afrikaans University, Johannesburg.

Momodu, O.M., 2012, 'Rural libraries and community in Nigeria', International Journa of Basic, Applied and Innovative Research 1(3), 91-97, viewed 21 October 2016, from https://www.ajol.info/index.php/ ijbair/article/view/108361

Mtega, W.P. \& Ronald, B., 2013, 'The state of rural information and communication services in Tanzania: A meta-analysis', International Journal of Information and Communication Technology Research 3(2), 64-73, viewed 21 March 2017, from http://41.73.194.142:8080/xmlui/bitstream/handle/123456789/1165/ Benard\%203.pdf?sequence $=1$ \&isAllowed $=y$

Mutshewa, A., Grand, B., Totolo, A., Zulu, S., Sebina, P. \& Jorosi, B., 2010, 'Information behaviours of non-users of libraries in Botswana', African Journal of Library Archival and Information Science 20(1), 1-10, viewed 28 April 2017, from http:/ ubrisa.ub.bw/bitstream/handle/10311/1099/Mutshewa_AJLAIS 2010. pdf?sequence $=1$ \&isAllowed $=y$.

Ngcobo, T.T., 2005, 'The role of community libraries in enhancing teaching and learning amongst school going learners: A case study of the Clermont Community Library', Unpublished master's thesis, Department of Education Studies, University of KwaZulu-Natal, Pietermaritzburg.

Nwalo, K.I.N. \& Madukoma, E., 2012, 'Sources, availability, and use of information for sustainability of petty trade in Ikenne Local Government Area, Ogun State, Nigeria', Global Journal of Human Social Science 12(4), 60-68, viewed 13 April 2017, from http://socialscienceresearch.org/index.php/GJHSS/article/ view/304.

Nwokocha, U., 1998, 'Public libraries in Nigeria: Decades of persisting problems', The International Information and Library Review 30(2), 97-104, viewed 14 April 2017, from http://www.tandfonline.com/doi/pdf/10.1080/10572317.1998.1076 2468? needAccess=true.

Nyana, S.A., 2009, 'Creating a library system that serves the needs of rural communities in Africa South of the Sahara', The Journal of Pan African Studies 3(1), 9-23.

Obasi, N.F.K., 2015, 'Indices of access to information in Nigerian public libraries and citizens' political participation', Paper delivered at the IFLA World Library and Information Congress held in Cape Town, 13-17 August.

Odefadehan, O.O., Akinola, A. \& Odefadehan, O., 2016, 'Information needs, access and use for social welfare and family planning by rural dwellers in Ido and Akinyele local government areas of Oyo state, Nigeria', Library Philosophy and Practice (e-Journal) 1415, 1-17, viewed 11 April 2017, from http://digitalcommons.unl. edu/cgi/viewcontent.cgi?article=3919\&context=libphilprac

Omar, S.Z., Shaffril, H.A.M., Bolong, J. \& D'Silva, J.L., 2012, 'Investigating rural library usage among rural youth in Malaysia: Its corresponding determinants and impacts', Computer and Information Science 5(2), 98-104, viewed 28 April 2017 from http://www.ccsenet.org/journal/index.php/cis/article/view/13694

Omopupa, K.T., 2006, 'The libraries of Nigeria and their role in promoting peace, unity and rural development', llorin Journal of Management Sciences 2(17), 9-16.

Oni, O., Nomuje, R.N. \& Oshiotse, J.O., 2014, 'Provision of information for rural development by information officers in some selected local government areas in Delta and Ondo states, Nigeria', PALGO Journal of Educational Research 2(2), 64-74.

Opara, U.N., 2008, 'The public library in contemporary Nigeria: Challenges and the way forward', International Federation of Library Associations and Institutions Journal 34(4), 349-358, viewed 16 April 2017, from http://journals.sagepub.com/ doi/pdf/ 10.1177/0340035208099270.

Oyeronke, A., 2012, 'Information as an economic resource: The role of public libraries in Nigeria', Chinese Librarianship: An International Electronic Journal 34, 66-75, viewed 2016, from www.iclc.us/cliej/cl34oyeronke.pdf.

Patience, O.U., 2015, 'Challenges of information dissemination to rural communities: A case of Niger-Delta communities, Nigeria', Journal of Emerging Trends in Computing and Information Science 6(7), 350-354.

Saleh, A.G. \& Lasisi, F.I., 2011, 'An assessment of public library services in North Eastern Nigeria', Library Philosophy and Practice 507, 1-8, viewed 16 April 2017, from http://digitalcommons.unl.edu/cgi/viewcontent.cgi?article=1525\&context= libphilprac.

Salman, A.A., Mostert, B.J. \& Mugwisi, T., 2013, 'Challenges in the provision and utilization of information services in public libraries in Nigeria: A literature survey', Paper delivered at the Libraries in Dialogue for Transformation and Innovation: 15th LIASA annual conference held in Cape Town, 4-11 October.

Sultana, R., 2014, 'Rural library services: Lesson from five rural public libraries in West Bengal', Journal of Humanities and Social Science Invention 3(10), 27-30, viewed 14 June 2016, from http://www.ijhssi.org/papers/v3(10)/Version-2/D031020 27030.pdf.

Tabor, A.E., 2009, 'Information for rural communities: A solution for sustainable development in the Niger Delta', Library Philosophy and Practice 309, 1-6, viewed 13 September 2016, from http://digitalcommons.unl.edu/libphilprac/309.

Thanuskodi, S. \& Pandiselvi, P., 2014, Information needs in rural women: A study of Tamil Nadu, India', E-Library Science Research Journal 2(8), 1-11.

Udofia, U.I., 2012, 'Information needs of rural secondary school adolescents in Nigeria', International Journal of Academic Research in Business and Socia Sciences 2(10), 296-304, viewed 30 April 2017, from http://www.hrmars.com/ admin/pics/1190.pdf.

Uzuegbu, C.P., 2016, 'Effective information service delivery to rural dwellers in SubSaharan Africa', International Federation of Library Associations Journal 42(1), 49-58, viewed 02 June 2017, from https://doi.org/10.1177/0340035215608860

Vavrek, B., 1995, 'Rural information needs and the role of the public library', Library Trend's 44(1), 21-49, viewed 02 June 2017, from https://www.ideals.illinois.edu/ bitstream/handle/2142/8006/librarytrendsv44i1d_opt.pdf?sequence=1. 
Williamson, K., 1998, 'Discovered by chance: The role of incidental information acquisition in an ecological model of information use', Library and Information acquistion ince sciencedirect.com/science/article/pii/S0740818898900044.

Wilson, T.D., 1981, 'On user studies and information needs', Journal of Documentation 37(1), 3-15.https://doi.org/10.1108/eb026702

Wilson, T.D., 1999, 'Model in information behaviour research', Journal of Documentation 55(3), 249-270. https://doi.org/10.1108/EUM0000000007145
Yusop, N.I., Ibrahim, H., Yusof, S.A.M., Aji, Z.M., Dahalin, Z.M., Ghazali, O. et al., 2013, 'Information needs of rural communities', The Journal of Community Informatics 9(1), viewed 28 April 2017, from http://ci-journal.net/index.php/ciej/article/ view/586/965.

Zou, C. \& Zou, P., 2014, 'Analysing information needs of elderly people: A survey in Chinese rural community', Open Journal of Social Sciences 2(09), 109-115, viewed 29 April 2017, from http://file.scirp.org/pdf/JSS_20140826111 21625.pdf 